\title{
Pathogenicity of Ceratocystis fimbriata from New Zealand kūmara on kiwifruit cultivars
}

\author{
Joy L. Tyson ${ }^{1,}$, Michael A. Manning ${ }^{1}$ and Peter J. Wright ${ }^{2}$ \\ ${ }^{1}$ The New Zealand Institute for Plant \& Food Research Limited, Private Bag 92169, Auckland, New Zealand \\ ${ }^{2}$ The New Zealand Institute for Plant \& Food Research Limited, Cronin Road, RD1, Pukekohe, New Zealand \\ *Corresponding author: Joy.Tyson@plantandfood.co.nz \\ (Original submission received 26 May 2020; accepted in revised form 24 July 2020)
}

\begin{abstract}
Ceratocystis fimbriata was reported in 2010 causing wilt and death of kiwifruit (Actinidia spp.) vines in Brazil, with losses of up to $50 \%$ of vines on some orchards. New Zealand is one of the largest producers of kiwifruit in the world, but C. fimbriata has been recorded only on kūmara (Ipomoea batatas) in this country. In this study the pathogenicity of New Zealand isolates of $C$. fimbriata from kūmara was examined using potted vines of four kiwifruit cultivars. During the trial, none of the vines became visibly diseased, growth rates were not restricted, and discolouration at the inoculation sites on the stem was minimal. In comparison, tests by researchers in Brazil using C. fimbriata isolated from symptomatic kiwifruit resulted in lengthy lesions and death of susceptible kiwifruit seedlings. Sequences of the internal transcribed spacer (ITS) region of rRNA from the New Zealand C. fimbriata isolates were $100 \%$ identical to those sequences from C. fimbriata isolates from Ipomoea batatas in GenBank. This study has shown that the New Zealand isolates of $C$. fimbriata from kūmara are not pathogenic to the kiwifruit cultivars tested, and are a different pathotype to those found on kiwifruit in Brazil.
\end{abstract}

Keywords Ipomoea batatas, sweet potato, Actinidia spp., pathogenicity testing

\section{INTRODUCTION}

Ceratocystis fimbriata is a fungal pathogen that affects a wide variety of plant hosts, in more than 22 families, many of which are of commercial importance. It was first identified on Ipomoea batatas in north-eastern USA in 1890 (Halsted 1890 ), and since then has been widely reported across the world. Ipomoea batatas is known as kūmara in New Zealand and as sweet potato in many other parts of the world, and this distinction is used here.

The first record of $C$. fimbriata in New Zealand was by Kirk (1907) causing black-rot of kūmara in the North Island. In 1947, it was reported on kūmara in Kaitaia and, by 1960, had also been recorded from the Bay of Islands, Helensville, Great Barrier Island, Auckland, Matakana Island (Bay of Plenty) and Gisborne (Slade 1960).

Ceratocystis fimbriata is now thought to be a complex of very similar fungal species with numerous different strains. Four phylogenetic clades are now recognised, including the Latin American clade (LAC) (Harrington et al. 2011), to which the Ipomoea strain belongs. Some of the strains of $C$. fimbriata appear to be host-specific, while others infect a range of hosts, including many of economic importance. Several are potentially different species, others (e.g. C. platani) have previously been raised to species level (Engelbrecht \& Harrington 2005). In 2014, C. fimbriata was reported on Ohi'a (Metrosideros polymorpha) in Hawai'i (Keith et al. 2015). It was subsequently shown that the rapid death of Ohi'a was caused by two distinct species within the Ceratocystis fimbriata complex; C. lukuohia and C. huliohia (Barnes et al. 2018).
Ceratocystis fimbriata sensu lato is a complex of soil-borne pathogens that cause wilt and cankers on woody plants, e.g. plane trees (Platanus spp.) and Eucalyptus spp. (Zauza et al. 2004; Tsopelas et al. 2017), as well as postharvest rots of storage roots and corms, e.g. taro (Colocasia esculenta) and sweet potato (Halsted \& Fairchild 1891; Harrington et al. 2005). Woody hosts tend to be invaded through wounds, although the pathogen may also move between hosts through root grafts and may also directly infect roots (Harrington 2013). In sweet potato/kūmara, infection may be through contaminated planting material (slips) but the pathogen is more often introduced directly through damaged roots, lenticels or wounds (Lewthwaite et al. 2011).

In South America, C. fimbriata is a native pathogen with a wide host range (Harrington et al. 2011; Ferreira et al. 2013). In 2010, it was reported causing wilt and death of kiwifruit (Actinidia spp.) vines in Rio Grande do Sul, Brazil (Sonego et al. 2010; Ferreira et al. 2013; Piveta et al. 2016). Subsequent phylogenetic analyses showed that the kiwifruit isolates belonged to three lineages within the LAC, suggesting three populations of $C$. fimbriata genotypes on kiwifruit (Ferreira et al. 2017). All kiwifruit isolates tested by Piveta et al. (2016) were pathogenic to kiwifruit and isolates from different ITS haplotypes did not differ widely in aggressiveness.

Symptoms of ceratocystis wilt in kiwifruit vines in Brazil include leaf curl and wilt, shrivelled canes, and a reddishbrown staining in the xylem tissues that is evident when the bark and inner wood is cut down the side of the trunk. The staining often forms a radial pattern in the trunk. Affected 
vines produce a reduced crop and most eventually die (Sonego et al. 2010; Ferreira et al. 2013; Piveta et al. 2016; Ferreira et al. 2017). On some orchards, there have been losses of $25-30 \%$ of vines each year and ceratocystis wilt is now a major limiting factor to the cultivation of kiwifruit in Brazil (Ferreira et al. 2017).

New Zealand is one of the largest producers of kiwifruit in the world (Pathirana et al. 2016), and the emergence of ceratocystis wilt in Brazilian kiwifruit represents a new biosecurity threat to the New Zealand industry. Although C. fimbriata is present in New Zealand, it has been recorded only on kūmara (Pennycook 1989; Anon. 2020). The lack of disease in New Zealand-grown kiwifruit has led to speculation that the new reports on kiwifruit in Brazil are of a different pathotype to that found in New Zealand. However, in New Zealand, kūmara and kiwifruit are not grown in close proximity and it may be that the pathogen is simply not present where kiwifruit are grown (geographic isolation).

To determine whether the absence of $C$. fimbriata on kiwifruit in New Zealand is the result of geographic isolation, this study examined the pathogenicity of New Zealand isolates of $C$. fimbriata from kūmara against potted kiwifruit vines.

\section{MATERIALS AND METHODS}

\section{Plant material}

Micro-propagated (tissue-cultured) plants of four kiwifruit cultivars, A. chinensis var. deliciosa 'Hayward', A. chinensis var. chinensis 'Zesy002' (Gold3) and A. chinensis var. chinensis x A. chinensis var. deliciosa 'Zesh004' (Green14) and A. macrosperma 'Bounty' were potted into 8-cm diameter planting bags and grown in a glasshouse (average temperature of $25 \pm 5^{\circ} \mathrm{C}$ ). At approximately 6 months posttissue culture, vines were transplanted into $12-\mathrm{cm}$ diameter potting bags containing sterile potting mix with slow-release fertiliser. The height of each vine was recorded immediately before inoculation and at harvest.

\section{Inoculum preparation}

The methods for inoculum preparation, inoculation, assessment and re-isolation as described by Baker et al. (2003) were followed.

Table 1 New Zealand isolates of Ceratocystis fimbriata used for pathogenicity testing. All isolates originate from kūmara (Ipomoea batatas).

\begin{tabular}{|c|c|c|c|}
\hline $\begin{array}{l}\text { ICMPa }^{a} \\
\text { accession no. }\end{array}$ & $\begin{array}{l}\text { GenBank } \\
\text { accession no. }\end{array}$ & $\begin{array}{l}\text { Collection } \\
\text { year }\end{array}$ & Location \\
\hline ICMP 894 & MT409623 & 1961 & $\begin{array}{l}\text { Auckland, } \\
\text { Mt Albert }\end{array}$ \\
\hline ICMP 1731 & MT412427 & 1966 & Auckland \\
\hline ICMP 2085 & MT412429 & 1967 & $\begin{array}{l}\text { Northland, } \\
\text { Ruawai }\end{array}$ \\
\hline ICMP 13575 & MT412426 & 1998 & Northland \\
\hline ICMP 13968 & MT412428 & 1999 & $\begin{array}{l}\text { Northland, } \\
\text { Ruawai }\end{array}$ \\
\hline
\end{tabular}

anternational Collection of Microorganisms from Plants
New Zealand isolates of $C$. fimbriata were obtained from the Manaaki Whenua Landcare Research International Collection of Micro-organisms from Plants (ICMP) and were all originally from kūmara (Table 1). Each isolate was grown on Difco potato dextrose agar (PDA) at room temperature for 5 days. Inoculum suspensions were prepared by flooding each culture with $10 \mathrm{~mL}$ sterile reverse osmosis (RO) water and lightly scraping the surface with a sterile spatula. The resulting spore suspension was filtered through sterile muslin (cotton). The concentration of the spores was estimated with a haemocytometer and diluted to $10^{6}$ spores per $\mathrm{mL}$ with sterile RO water. Controls were prepared by flooding and scraping a sterile PDA plate.

Each New Zealand isolate was also directly inoculated onto carrot discs to check that they had retained pathogenicity during storage.

\section{Inoculation}

Kiwifruit vines were inoculated while actively growing (March 2015). Five plants (replicates) of each kiwifruit cultivar were inoculated with each treatment (five isolates of $C$. fimbriata and the water control).

An approximately 3-mm deep, downward-slanting cut was made from the outer bark to the inner wood with a sterile scalpel, $3 \mathrm{~cm}$ from the base of the plant. An aliquot of $100 \mu \mathrm{L}$ of the spore suspension or control suspension was injected into each wound with a pipette, and the inoculation site was wrapped in Parafilm ${ }^{\circledR}$. The Parafilm was removed after $24 \mathrm{~h}$.

Plant height was recorded immediately before inoculation and at harvest. Plants were laid out in a complete block design in the greenhouse, observed regularly and harvested 28 days after inoculation (Baker et al. 2003).

\section{Assessment and re-isolation}

At harvest, 28 days after inoculation, the lower stem of each plant was sliced open vertically above and below the point of inoculation, and the length of xylem discolouration recorded. To establish whether the inoculum remained alive in the vine tissues, the stems were surface sterilised with a dilute solution of $\mathrm{NaOCl}$ and rinsed twice in sterile RO water, then pieces of discoloured tissue (or tissue from the inoculation site if there was no discolouration) were placed between slices of carrot and incubated under humid conditions at room temperature (Moller \& Devay 1968). Isolations were also made from the inoculation site onto PDA amended with rifampicin and ampicillin. For ten representative vines with more obvious discolouration (lesion lengths of $2 \mathrm{~cm}$ or greater), re-isolation was also attempted from the inoculation site and at 2 and $5 \mathrm{~cm}$ above the inoculation site. Identification of the re-isolated fungi was by standard morphological techniques.

The length of xylem discolouration in each isolation/ cultivar combination was compared using multifactorial ANOVA (Minitab 18) using Tukey's test $(\mathrm{P}<0.05)$.

\section{ITS sequencing}

DNA was extracted from mycelia of the five New Zealand C. fimbriata isolates using a QIAGEN DNeasy ${ }^{\circledR}$ Plant Mini Kit, following the manufacturer's instructions. 
The rRNA internal transcribed spacer (ITS) regions of all isolates were amplified by PCR with the universal primers ITS1 and ITS4 (White et al. 1990). PCR products were visualised on a $1.6 \%$ agarose gel and then purified using a QIAGEN QIAquick PCR Purification Kit, following manufacturer's instructions, and sequenced at Ecogene (Auckland, New Zealand).

The most likely taxonomic identity of each fungal isolate was determined using the Geneious BLASTn function to compare their sequences with those stored in the GenBank nucleotide redundant database.

Representative sequences, retrieved from GenBank, from previous studies of $C$. fimbriata isolated from kiwifruit (Piveta et al. 2016), from the LAC ITS groupings of Harrington et al. (2011) and from isolates from sweet potato from various countries along with one other member of the LAC (C. platani) were compared with sequences from the isolates from New Zealand kūmara (Table 2). Phylogenetic analyses of the ITS sequences were performed via Geneious Pro 10.0.3 (Biomatters, Auckland, New Zealand) using RAxML ver. 8 (Stamatakis 2014) for tree construction. Topology was rooted with $C$. variospora (North American Clade) and bootstrap values were 100 from 10,000 replicates.

\section{RESULTS}

\section{Pathogenicity testing}

At harvest, 28 days after inoculation, none of the kiwifruit vines were visibly diseased and none had died. Growth rates were not restricted (data not shown). Overall, there was very little discolouration in the tissues of the inoculated vines, with an average discolouration length of $0.75 \mathrm{~cm}$ (range 0-4 cm), centred on the wound site, and not much larger than the inoculation wound. The discolouration was restricted to directly beneath the wound site and did not extend further than the xylem; in many of the vines this was very faint and seemed to be a result of the wound reaction combined with the dark spore suspension. There was no discolouration in the stems of any of the water-inoculated control vines. There was no significant difference $(\mathrm{P}=0.05)$ in the length of discolouration between any of the isolate cultivar combinations and the control treatments (Table 3).

Ceratocystis fimbriata was re-isolated from the wound site of $73 \%$ of the inoculated vines, but was not able to be isolated $2 \mathrm{~cm}$ from the wound. It was not recovered from the control plants.

Direct inoculations onto carrot discs from all four New Zealand isolates resulted in rots with visible grey mycelium that formed typical long-necked Ceratocystis perithecia after 7-14 days.

\section{ITS sequencing}

The ITS region was amplified, using primers ITS 1 and 4 (White et al. 1990), from the five New Zealand isolates from kūmara, producing an amplicon of approximately $541 \mathrm{bp}$. The sequences of the amplified products were deposited in the GenBank database and assigned accession numbers MT409623, MT412426, MT412427, MT412428 and MT412429. BLASTn analysis of the ITS amplicon from the kūmara isolates from New Zealand were $100 \%$ identical to those of the overseas sweet potato isolates.

Analysis of neighbour-joining trees of the ITS sequences generated in Geneious 10.0.3 (Biomatters, Auckland, New Zealand) placed the New Zealand kūmara isolates with the sweet potato isolates from other countries (Figure 1). Sequences from kiwifruit in Brazil clustered into different groups.

\section{DISCUSSION}

The results from this project showed the New Zealand isolates of $C$. fimbriata from kūmara were not pathogenic on kiwifruit vines. None of the kiwifruit vines became visibly diseased or died, growth rates were not restricted, and the length of the discolouration at the inoculation sites was minimal (mean $0.7 \mathrm{~cm}$ ). In comparison, pathogenicity tests on kiwifruit in Brazil using the $C$. fimbriata isolated from kiwifruit have resulted in lengthy lesions, with means of $7.7-68.4 \mathrm{~cm}$, depending on the cultivar/isolate combination, as well as the death of approximately $30 \%$ of the inoculated plants over two experiments (Piveta et al. 2016).

Baker et al. (2003) found that sweet potato C. fimbriata isolates inoculated into sweet potato plants resulted in an average xylem discolouration of $4.3 \mathrm{~cm}$ after 28 days, significantly larger than the $0.7 \mathrm{~cm}$ discolouration seen in the inoculated kiwifruit in this study. In a further 45-day experiment with isolates from three hosts, they found that sweet potato isolates inoculated into sweet potato, cacao (Theobroma sp.) and sycamore (Platanus sp.) only resulted in the death of sweet potato plants (17\%), whereas cacao and sycamore $C$. fimbriata isolates resulted in the death of $93 \%$ of inoculated cacao and $70 \%$ of inoculated sycamore, respectively.

Symptoms of $C$. fimbriata in kiwifruit vines in Brazil include leaf curl and wilt, shrivelled canes, and darkened xylem tissues that are evident when the bark and inner wood is cut down the side of the trunk. Ferreira et al. (2013) noted that affected plants have reddish-brown staining in a radial pattern in the xylem and the disease reduces the number of harvestable fruit. Most affected plants die. To date, $C$. fimbriata has not been identified from New Zealand kiwifruit vines and no obvious symptoms have been seen.

In New Zealand, commercial kūmara and kiwifruit are not grown in close proximity and it was unknown if the pathogen was not a problem to kiwifruit simply because it was geographically separated. The results from this study show that the kümara strain of $C$. fimbriata does not appear to be pathogenic to the four kiwifruit cultivars tested and the strains present are genetically different from the isolates in Brazil that are pathogenic to kiwifruit. The absence of $C$. fimbriata and disease symptoms in New Zealand kiwifruit orchards is likely because of the absence of strains pathogenic to kiwifruit in New Zealand.

It has been previously recognised that some lineages of the C. fimbriata species complex show more host specialisation than others. Several strains that show clear host specialisation has been raised to species (Harrington et al. 2014), including C. platani, which has adapted to Platanus occidentalis, and C. cacaofunesta, which has adapted to Theobroma spp. (Engelbrecht \& Harrington 2005).

The Ipomoea strain appears to be pathogenic only 
Table 2 Origin and GenBank accession number of Ceratocystis sp. isolates used to create the maximum likelihood tree illustrating the phylogenetic relationships between the sweet potato, kiwifruit and other related $C$. fimbriata strains.

\begin{tabular}{|c|c|c|c|c|c|c|}
\hline $\begin{array}{l}\text { Ceratocystis } \\
\text { species }\end{array}$ & $\begin{array}{l}\text { GenBank } \\
\text { Accession No. }\end{array}$ & Isolate No. & Host plant & Country & $\begin{array}{l}\text { ITS } \\
\text { group }\end{array}$ & Reference \\
\hline C. fimbriata & KJ469358 & PL11 & Actinidia deliciosa & Brazil & KiwiA & Piveta et al. (2016) \\
\hline C. fimbriata & KJ469350 & РCT01 & Actinidia deliciosa & Brazil & KiwiA & Piveta et al. (2016) \\
\hline C. fimbriata & KJ469342 & PA25 & Actinidia deliciosa & Brazil & KiwiA & Piveta et al. (2016) \\
\hline C. fimbriata & KJ469363 & PP08 & Actinidia deliciosa & Brazil & KiwiB & Piveta et al. (2016) \\
\hline C. fimbriata & KJ469356 & PL01 & Actinidia deliciosa & Brazil & KiwiC & Piveta et al. (2016) \\
\hline C. fimbriata & KJ469347 & PC03 & Actinidia deliciosa & Brazil & KiwiC & Piveta et al. (2016) \\
\hline C. fimbriata & KJ469346 & PB67 & Actinidia deliciosa & Brazil & KiwiC & Piveta et al. (2016) \\
\hline C. fimbriata & KJ469364 & PP14 & Actinidia deliciosa & Brazil & KiwiD & Piveta et al. (2016) \\
\hline C. fimbriata & KJ469345 & РВ09 & Actinidia deliciosa & Brazil & KiwiD & Piveta et al. (2016) \\
\hline C. fimbriata & KJ469344 & PB01 & Actinidia deliciosa & Brazil & KiwiD & Piveta et al. (2016) \\
\hline C. fimbriata & AY526286 & C1865 & Colocasia esculenta & Brazil & ITS11 & Harrington et al. (2011) \\
\hline C. fimbriata & HQ157541 & C1926 & Colocasia esculenta & Brazil & ITS12 & Harrington et al. (2011) \\
\hline C. fimbriata & AY526288 & C1905 & Colocasia esculenta & Brazil & ITS13 & Harrington et al. (2011) \\
\hline C. fimbriata & HQ157540 & C1914 & Colocasia esculenta & Brazil & ITS9 & Harrington et al. (2011) \\
\hline C. fimbriata & HQ157544 & C1440 & Eucalyptus sp. & Brazil & ITS3 & Harrington et al. (2011) \\
\hline C. fimbriata & HQ157545 & C1442 & Eucalyptus sp. & Brazil & ITS4 & Harrington et al. (2011) \\
\hline C. fimbriata & HQ157543 & C1988 & Eucalyptus sp. & Brazil & ITS5 & Harrington et al. (2011) \\
\hline C. fimbriata & AY157966 & C1345 & Eucalyptus sp. & Brazil & ITS5 & Harrington et al. (2011) \\
\hline C. fimbriata & HQ157542 & C1857 & Ficus carica & Brazil & ITS1 & Harrington et al. (2011) \\
\hline C. fimbriata & AY526292 & C1782 & Ficus carica & Brazil & ITS8 & Harrington et al. (2011) \\
\hline C. fimbriata & AY157967 & C925 & Gmelina arborea & Brazil & ITS15 & Harrington et al. (2011) \\
\hline C. fimbriata & HQ157539 & C924 & Gmelina arborea & Brazil & ITS16 & Harrington et al. (2011) \\
\hline C. fimbriata & MT412429 & ICMP 2085 & Ipomoea batatas & New Zealand & - & this study \\
\hline C. fimbriata & MT412428 & ICMP 13968 & Ipomoea batatas & New Zealand & - & this study \\
\hline C. fimbriata & MT412427 & ICMP 1731 & Ipomoea batatas & New Zealand & - & this study \\
\hline C. fimbriata & MT412426 & ICMP 13575 & Ipomoea batatas & New Zealand & - & this study \\
\hline C. fimbriata & MT409623 & ICMP 894 & Ipomoea batatas & New Zealand & - & this study \\
\hline C. fimbriata & AY157957 & C1476 & Ipomoea batatas & USA & ITS1a & Harrington et al. (2011) \\
\hline C. fimbriata & AY157956 & C1418 & Ipomoea batatas & $\begin{array}{l}\text { Papua New } \\
\text { Guinea }\end{array}$ & ITS1a & Harrington et al. (2011) \\
\hline C. fimbriata & KU043253 & strain D & Ipomoea batatas & USA & - & Heller, unpub. \\
\hline C. fimbriata & KC493160 & CBS114723 & Ipomoea batatas & USA & - & Luchi \& Belbahri, unpub. \\
\hline C. fimbriata & AF007749 & C854 & Ipomoea batatas & USA & - & Witthuhn et al. (1998) \\
\hline C. fimbriata & AY157964 & C994 & Mangifera indica & Brazil & ITS10 & Harrington et al. (2011) \\
\hline C. fimbriata & AY526291 & C1688 & Mangifera indica & Brazil & ITS14 & Harrington et al. (2011) \\
\hline C. fimbriata & AY157965 & C1558 & Mangifera indica & Brazil & ITS9 & Harrington et al. (2011) \\
\hline C. fimbriata & HQ157546 & C1655 & Mangifera sp. & Brazil & ITS2 & Harrington et al. (2011) \\
\hline C. fimbriata & HQ157548 & C2055 & Mangifera sp. & Brazil & ITS6 & Harrington et al. (2011) \\
\hline C. fimbriata & HQ157547 & C1889 & Mangifera sp. & Brazil & ITS7 & Harrington et al. (2011) \\
\hline C. platani & AY157958 & C1317 & $\begin{array}{l}\text { Platanus } \\
\text { occidentalis }\end{array}$ & USA & - & Baker et al. (2003) \\
\hline C. platani & MH864607 & CBS 127659 & Platanus orientalis & Greece & - & Vu et al. (2019) \\
\hline C. variospora & AY907045 & C1965 & Prunus serotina & USA & - & Johnson et al. (unpub.) \\
\hline
\end{tabular}


Table 3 Mean length $(\mathrm{cm})$ of stem discolouration (SD) and number of dead plants (NDP) in four cultivars of kiwifruit ${ }^{\mathrm{a}}$ inoculated with five New Zealand isolates of Ceratocystis fimbriata from kūmara (Ipomoea batatas).

\begin{tabular}{llclllllc}
\hline & \multicolumn{2}{c}{ 'Hayward' } & \multicolumn{2}{c}{ Gold3 } & \multicolumn{2}{c}{ Green14 } & \multicolumn{2}{c}{ 'Bounty' } \\
\hline Isolate number & SD $^{\mathrm{b}}$ & NDPc & SD & NDP & SD & NDP & SD & NDP \\
\hline ICMP 894 & $1.0 \mathrm{a}^{*}$ & 0 & $0.9 \mathrm{a}$ & 0 & $0.4 \mathrm{a}$ & 0 & $1.1 \mathrm{a}$ & 0 \\
ICMP 1731 & $1.4 \mathrm{a}$ & 0 & $0.6 \mathrm{a}$ & 0 & $0.4 \mathrm{a}$ & 0 & $0.4 \mathrm{a}$ & 0 \\
ICMP 2085 & $1.6 \mathrm{a}$ & 0 & $0.6 \mathrm{a}$ & 0 & $0.7 \mathrm{a}$ & 0 & $0.7 \mathrm{a}$ & 0 \\
ICMP 13575 & $1.0 \mathrm{a}$ & 0 & $0.1 \mathrm{a}$ & 0 & $0.6 \mathrm{a}$ & 0 & $0.2 \mathrm{a}$ & 0 \\
ICMP 13968 & $0.7 \mathrm{a}$ & 0 & $1.1 \mathrm{a}$ & 0 & $0.7 \mathrm{a}$ & 0 & $0.7 \mathrm{a}$ & 0 \\
control & $0.0 \mathrm{a}$ & 0 & $0.0 \mathrm{a}$ & 0 & $0.0 \mathrm{a}$ & 0 & $0.0 \mathrm{a}$ & 0 \\
\hline
\end{tabular}

actinidia chinensis var. deliciosa 'Hayward'; A. chinensis var. chinensis 'Zesy002' (Gold3); A. chinensis var. chinensis $\mathrm{x}$ A. chinensis var. deliciosa 'Zesh004' (Green14); A. macrosperma 'Bounty'

${ }^{\mathrm{b}} \mathrm{SD}=$ stem discolouration

${ }^{\mathrm{c}} \mathrm{NDP}=$ number of dead plants out of five inoculated plants

*Means that share a letter are not significantly different $(\mathrm{P}=0.05)$.

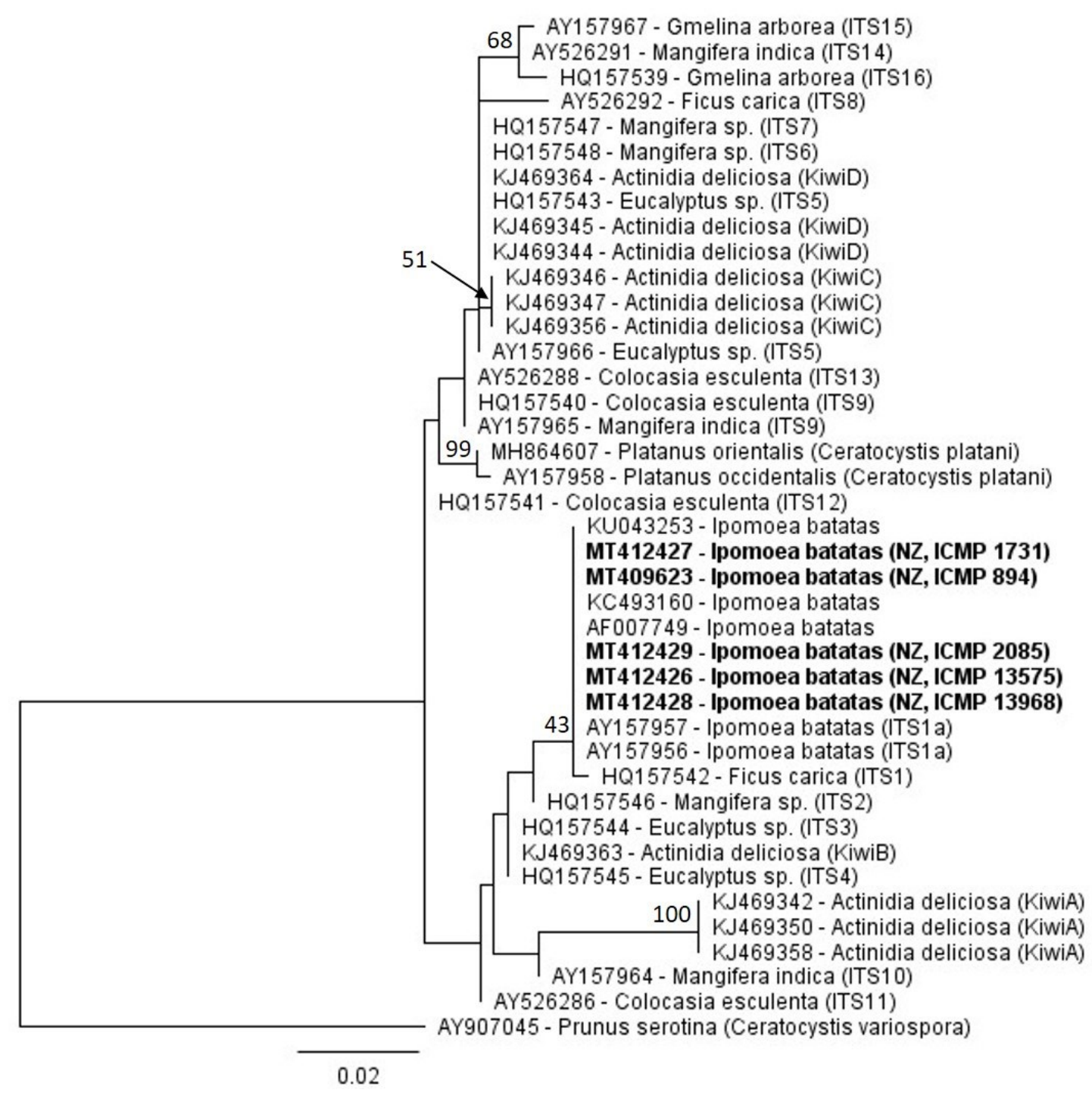

Figure 1 Maximum likelihood tree illustrating the phylogenetic relationships between the New Zealand Ipomoea batatas strains of Ceratocystis fimbriata (in bold type), representative strains from Brazilian Actinidia spp. and other related C. fimbriata strains. The internal transcribed spacer (ITS) groupings are from Harrington et al. (2011) and the Actinidia (Kiwi) groups are those of Piveta et al. (2016). 
to sweet potato, and is the strain for which the name C. fimbriata was first introduced (Marincowitz et al. 2020). Worldwide, members of this strain are genetically very close (Li et al. 2016). Baker et al. (2003) found that isolates from sweet potato all shared a unique ITS sequence and, in inoculation experiments, caused dramatically more xylem discolouration on sweet potato than on cacao or sycamore. In this study, the Ipomoea isolates from New Zealand had low genetic diversity in the ITS regions despite being isolated over a number of years (1961-1999). The low genetic diversity in the sweet potato lineage worldwide is thought to be because of the clonal spread of the pathogen on sweet potato storage roots from a single source population (Steimel et al. 2004). The name $C$. fimbriata f. sp. ipomoea was proposed for this strain (Valdetaro et al. 2019), however, Marincowitz et al. (2020) who have recently designated an epitype for $C$. fimbriata, treat this name as a synonym of C. fimbriata sensu stricto.

This study has shown that the New Zealand kūmara isolates of $C$. fimbriata are not pathogenic on the kiwifruit cultivars tested, and there is unlikely to be a threat from the New Zealand Ipomoea strain moving into kiwifruit orchards. However, the New Zealand kiwifruit industry does need to be vigilant in monitoring for new strains of the $C$. fimbriata species complex. Growers should be alert for symptoms similar to those described from Brazilian orchards (https:// www.kvh.org.nz/biosecurity).

Next steps should be screening of the Brazilian kiwifruit strains of the pathogen against selected New Zealand kiwifruit cultivars. This will allow kiwifruit varieties of commercial value with tolerance to ceratocystis wilt to be identified and included in breeding programmes.

\section{ACKNOWLEDGEMENTS}

This study was funded by Kiwifruit Vine Health (KVH). We thank Andrew Dunstan of Southern Cross Horticulture for kindly providing the 'Bounty' plants and Rob Taylor (Ministry for Primary Industries) for helpful comments on the manuscript.

\section{REFERENCES}

Anon. 2020. New Zealand fungi and bacteria (NZFUNGI). Retrieved May 2020, from https://nzfungi2. landcareresearch.co.nz/

Baker CJ, Harrington TC, Krauss U, Alfenas AC 2003. Genetic variability and host specialization in the Latin American clade of Ceratocystis fimbriata. Phytopathology 93: 1274-1284. $\quad$ https://doi.org/10.1094/ PHYT0.2003.93.10.1274

Barnes I, Fourie A, Wingfield MJ, Harrington TC, McNew DL, Sugiyama LS, Luiz BC, Heller WP, Keith LM 2018. New Ceratocystis species associated with rapid death of Metrosideros polymorpha in Hawai'i. Persoonia 40: 154181. https://doi.org/10.3767/persoonia.2018.40.07

Engelbrecht CJB, Harrington TC 2005. Intersterility, morphology and taxonomy of Ceratocystis fimbriata on sweet potato, cacao and sycamore. Mycologia 97: 57-69. https://doi.org/10.3852/mycologia.97.1.57

Ferreira MA, Harrington TC, Piveta G, Alfenas AC 2013. Genetic variability suggests that Ceratocystis fimbriata is native to Rio Grande do Sul, Brazil, where it is causing a new wilt disease on kiwifruit. Phytopathology 103: 43.

Ferreira MA, Harrington TC, Piveta G, Alfenas AC 2017. Genetic variability suggests that three populations of Ceratocystis fimbriata are responsible for the ceratocystis wilt epidemic on kiwifruit in Brazil. Tropical Plant Pathology 42: 86-95. https://doi.org/10.1007/ s40858-017-0131-y

Halsted BD 1890. Some fungous diseases of the sweet potato. New Jersey Agricultural College, Experimental Station Bulletin 76: 25-27.

Halsted BD, Fairchild DG 1891. Sweet-potato black rot (Ceratocystis fimbriata, Ell. \& Hals.). Journal of Mycology 7: 1-11. https://doi.org/10.2307/3752742

Harrington TC, Thorpe DJ, Marinho VLA, Furtado EL 2005. First report of black rot of Colocasia esculenta caused by Ceratocystis fimbriata in Brazil. Fitopatologia Brasileira 30: 88-89. https://doi.org/10.1590/S010041582005000100017

Harrington TC, Thorpe DJ, Alfenas AC 2011. Genetic variation and variation in aggressiveness to native and exotic hosts among Brazilian populations of Ceratocystis fimbriata. Phytopathology 101: 555-566. https://doi. org/10.1094/PHYT0-08-10-0228

Harrington TC 2013. Ceratocystis diseases. In: Gonthier $P$, Nicolotti G Ed. Infectious forest diseases. Wallingford; UK CABI. Pp. 230-255. https://doi. org/10.1079/9781780640402.0230

Harrington TC, Kazmi MR, Al-Sadi AM, Ismail SI 2014. Intraspecific and intragenomic variability of ITS rDNA sequences reveals taxonomic problems in Ceratocystis fimbriata sensu stricto. Mycologia 106: 224-242. https:// doi.org/10.3852/13-189

Keith LM, Hughes RF, Sugiyama LS, Heller WP, Bushe BC, Friday JB 2015. First report of ceratocystis wilt on 'Ōhi`a (Metrosideros polymorpha). Plant Disease 99: 1276. https://doi.org/10.1094/PDIS-12-14-1293-PDN

Kirk TW 1907. Divisions of Biology, Horticulture, and Publications. Report of T.W. Kirk, Biologist, Chief of Divisions. New Zealand Department of Agriculture, Annual Report 7: 135-258.

Lewthwaite SL, Wright PJ, Triggs CM 2011. Sweetpotato cultivar susceptibility to infection by Ceratocystis fimbriata. New Zealand Plant Protection 64: 1-6. https:// doi.org/10.30843/nzpp.2011.64.5973

Li Q, Harrington TC, McNew D, Li J, Huang Q, Somasekhara YM, Alfenas AC 2016. Genetic bottlenecks for two populations of Ceratocystis fimbriata on sweet potato and pomegranate in China. Plant Disease 100: 22662274. https://doi.org/10.1094/PDIS-03-16-0409-RE

Marincowitz S, Barnes I, De Beer ZW, Wingfield MJ 2020. Epitypification of Ceratocystis fimbriata. Fungal Systematics and Evolution 6: 289-298. https://doi. org/10.3114/fuse.2020.06.14

Moller WJ, Devay JE 1968. Carrot as a species-selective isolation medium for Ceratocystis fimbriata. Phytopathology 58: 123-124.

Pathirana R, Deroles S, Hoeata K, Montefiori M, Tyson JL, Wang T, Datson PM, Hellens RP 2016. Fasttracking kiwifruit breeding through mutagenesis. 
Acta Horticulturae 1127: 217-222. https://doi. org/10.17660/ActaHortic.2016.1127.34

Pennycook SR 1989. Plant diseases recorded in New Zealand. Auckland, New Zealand, Plant Diseases Division, DSIR. $276 \mathrm{p}$.

Piveta G, Ferreira MA, Muniz MdFB, Valdetaro D, Valdebenito-Sanhueza R, Harrington TC, Alfenas AC 2016. Ceratocystis fimbriata on kiwifruit (Actinidia spp.) in Brazil. New Zealand Journal of Crop and Horticultural Science 44: 13-24. https://doi.org/10.1080/01140671. $\underline{2016.1143020}$

Slade DA 1960. Black rot - an important disease of kumaras. New Zealand Journal of Agriculture 100: 375-378.

Sonego OR, Ferreira MA, Sanhueza RM, Gava R, Garrido LR, Alfenas AC 2010. First report of Ceratocystis wilt in kiwi. (Primeiro relato da murcha-de-ceratocystis em kiwi). Tropical Plant Pathology 35: S233.

Stamatakis A 2014. RaxML version 8: a tool for phylogenetic analysis and post-analysis of large phylogenies. Bioinformatics 30: 1312-1313. https://doi. org/10.1093/bioinformatics/btu033

Steimel J, Engelbrecht CJB, Harrington TC 2004. Development and characterization of microsatellite markers for the fungus Ceratocystis fimbriata. Molecular Ecology Notes 4: 215-218. https://doi.org/10.1111/j.14718286.2004.00621.x

Tsopelas P, Santini A, Wingfield MJ, de Beer ZW 2017. Canker Stain: A lethal disease destroying iconic plane trees. Plant Disease 101: 645-658. https://doi.org/10.1094/ PDIS-09-16-1235-FE

Valdetaro DCOF, Harrington TC, Oliveira LSS, Guimarães LMS, McNew DL, Pimenta LVA, Gonçalves RC, Schurt DA, Alfenas AC 2019. A host specialized form of Ceratocystis fimbriata causes seed and seedling blight on native Carapa guianensis (andiroba) in Amazonian rainforests. Fungal Biology 123: 170-182. https://doi. org/10.1016/j.funbio.2018.12.001

Vu D, Groenewald M, de Vries M, Gehrmann T, Stielow B, Eberhardt U, Al-Hatmi A, Groenewald JZ, Cardinali G, Houbraken J, Boekhout T, Crous PW, Robert V, Verkley GJM 2019. Large-scale generation and analysis of filamentous fungal DNA barcodes boosts coverage for kingdom fungi and reveals thresholds for fungal species and higher taxon delimitation. Studies in Mycology 92: 135-154. https://doi.org/10.1016/j. simyco.2018.05.001

White TJ, Bruns T, Lee S, Taylor J 1990. Amplification and direct sequencing of fungal ribosomal RNA genes for phylogenetics. In: Innis MA, Gelfand DH, Sninsky JJ, White TJ Ed. PCR Protocols: A Guide to Methods and Applications. New York, Academic Press, Inc. Pp. 315322. https://doi.org/10.1016/B978-0-12-3721808.50042-1

Witthuhn RC, Wingfield BD, Wingfield MJ, Wolfaardt M, Harrington TC 1998. Monophyly of the conifer species in the Ceratocystis coerulescens complex based on DNA sequence data. Mycologia 90: 96-101. https://doi.org/1 $\underline{0.1080 / 00275514.1998 .12026884}$

Zauza EAV, Alfenas AC, Harrington TC, Mizubuti ES, Silva JF 2004. Resistance of Eucalyptus clones to Ceratocystis fimbriata. Plant Disease 88: 758-760. https://doi. org/10.1094/PDIS.2004.88.7.758 